T. Shokol, PhD, shokol tv@univ.kiev.ua,

N. Gorbulenko, PhD,

V. Khilya, Dr. Sci., Corresponding Member of the NAS of Ukraine

Taras Shevchenko National University of Kyiv, Kyiv

\title{
SYNTHESIS OF 7-HYDROXY-2,8-DIMETHYL-4-OXO-3-PHENOXY-4H-6-CHROMENECARBALDEHYDE
}

Ortho-hydroxyformylchromones are convenient synthones for the construction of linear and angular hetarenochromones. Usually, 7-hydroxy-6formylchromones were synthesized by oxidation of natural linear furochromones: visnagin and kellin and their synthetic analogues. The Duff reaction, which is the formylation of phenols in the ortho-position by heating with hexamethylenetetramine followed by acidic hydrolysis of intermediate imine, was also used to convert 7-hydroxychromones into 7-hydroxy-6-formylchromones, but in this case there were some difficulties because of the passivity of position 6 in 7-hydroxychromones compared to position 8 to the electrophilic attack. Thus, for the preparation of 7-hydroxy-6formylchromones, it is necessary to use 8-substituted derivatives and to provide formylation for a long time. A method for the synthesis of 7-hydroxy6-formylchromones based on 8-substituted 7-hydroxy-6-dialkylaminomethylchromones and hexamethylenetetramine was developed using the Duff reaction conditions. This method was demonstrated on the synthesis of 7-hydroxy-2,8-dimethyl-4-oxo-3-phenoxy-4H-6-chromenecarbaldehyde from 6-dimethylaminomethyl-7-hydroxy-2,8-dimethyl-3-phenoxy-4H-4-chromenone and hexamethylenetetramine in glacial acetic acid at reflux. It should be noted that when carrying out this reaction under heating on a water bath with subsequent hydrochloric acid hydrolysis only Mannich base hydrochloride was isolated from the reaction mixture.

The starting 6-dimethylaminomethyl-7-hydroxy-2,8-dimethyl-3-phenoxy-4H-4-chromenone was synthesized from 1-(2,4-dihydroxy-3methylphenyl)-2-phenoxyethanone in three steps. Acylation of the latter with acetic anhydride in the presence of trimethylamine followed by condensation afforded 2,8-dimethyl-4-oxo-3-phenoxy-4H-7-chromenylacetate. Subsequent removal of acetyl protection resulted in 7-hydroxy-2,8dimethyl-3-phenoxy-4H-4-chromenone, which on introduction into the Mannich reaction with bisdimethylaminomethane in dioxane gave rise to the desired 6-dimethylaminomethyl derivative.

Keywords: 6-dialkylaminomethyl-7-hydroxy-4H-4-chromenones, 7-hydroxy-4-oxo-4H-6-chromenecarbaldehydes, Duff reaction.

УДК 547.759.4

DOI: https://doi.org/10.17721/1728-2209.2018.1(55).14

С. Крикун, асп., krykun.serhii@gmail.com, І. Левков, канд. хім. наук,

Т. Єгорова, канд. хім. наук,

3. Войтенко, д-р хім.наук

Київський національний університет імені Тараса Шевченка, Київ

\section{СИНТЕЗ ОКИСНЕНОї ФОРМИ ДИТІЕНО-ТТФ МЕТОДОМ ЕЛЕКТРОКРИСТАЛІЗАЦІЇ}

Показано ефективну методику для отримання кристалів окисненої форми, проаналізовано вплив розчинників, температури та підтримуючого електроліту на перебіе процесу. Показано, що сполука дитієно-ТТФ кристалізується у формі солі катіон-радикалу, на відміну від очікуваного дикатіона.

Ключові слова: електрокристалізація, тетратіофульвален, ТTФ.

Вступ. Сполуки з чітко вираженими оборотними окисно-відновними властивостями представляють інтерес у багатьох галузях науки і техніки. Одним із основних способів характеризації електронних властивостей $є$ електрохімія [1-3], найпоширенішими методами якої $\epsilon$ циклічна вольтаметрія, хроноамперометрія, контрольований електроліз, спектроелектрохімія та скануюча електрохімічна мікроскопія (SECM). Одним з найпотужніших інструментальних методів електрохімії $є$ електрокристалізація, що дозволяє отримати в чистому вигляді кристали окисненої форми для подальших досліджень.

Перші експерименти у цій галузі почались практично відразу після відкриття постійного струму, однак спочатку основною сферою використання методу була неорганічна хімія, починаючи ще з експериментів Фарадея і до промислового застосування в електропокритті та гальваноформуванні. Перший електролітичний експеримент, внаслідок якого вдалось отримати монокристал органічної сполуки, було описано в 1971 р. [4]. За рахунок гальваностатичного окиснення аренів, таких як перилен, пірен чи азулен, в розчині ТГФ 3 - Bu$_{4} \mathrm{ClO}_{4}$ в ролі електроліту було отримано темні кристали, які за результатами елементного та рентгеноструктурного аналізу ідентифікували як солі змішаної валентності $(\mathrm{Ar})_{2} \mathrm{ClO}_{4}$. При цьому автор відмітив, що кристали проводять струм і тому продовжують рости на електроді. Це стало основою для розвитку нової методики отримання солей окиснених форм органічних сполук. Подальший поштовх відбувся в 1973 р. після відкриття металічної провідності $[5,6]$ для солі з переносом заряду, отриманої шляхом хімічного окиснення суміші донорного тетратіофульвалену (ТТФ, TTF $[7,8])$ та акцепторного тетраціанохінодиметану (TЦHX, TCNQ [9]) з утворенням комплексу ТТФ-ТЦНХ (TTF-TCNQ). Як наслідок, було синтезовано різноманіття донорних молекул на базі ТТФ [10], які далі було пов'язано з ТЦНХ та тетрафтортетраціанохінодиметаном (TЦHXF 4 ) для дослідження ефектів хімічних та структурних модифікацій базової системи ТТФ-
ТЦНХ. Також була показана гальваностатична електрокристалізація чистого ТТФ у присутності різних протиіонів $\left(\mathrm{X}^{-}=\mathrm{NO}_{3}^{-}, \mathrm{Br}, \mathrm{HCO}_{3}^{-}, \mathrm{BF}_{4}^{-}\right)$з утворенням солей із змішаною валентністю ТТФ $\mathrm{n}$ [11]. Було проілюстровано явище надпровідності $\left(T_{c}=9 \mathrm{~K}\right)$ для тетраметилтетраселенофульвалену (ТМТСФ) $2 \mathrm{PF}_{6}$ при 12 кбар і пізніше для $(\text { TMTC } \Phi)_{2} \mathrm{ClO}_{4}\left(T_{c}=1.2 \mathrm{~K}\right)$ при атмосферному тиску [12].

Структурний фрагмент ТТФ та його похідні продовжують бути актуальними завдяки використанню в галузях молекулярних напівпровідників [13-16], органічних транзисторів [17], фоотовольтаїці [18] та сонячних комірках [19].

Обговорення. Одною з основних властивостей структурного фрагменту ТТФ є здатність до оборотного окиснення з утворенням спочатку катіон-радикала ТТ $\Phi^{*+}$, а

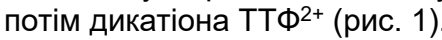

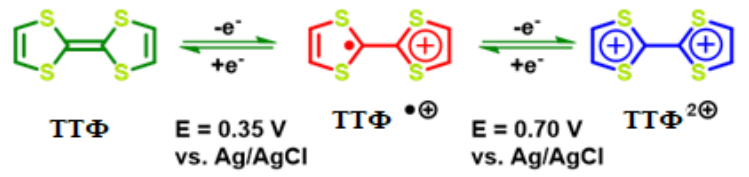

Рис. 1. Схема окиснення ТТФ

Для подальшого контролю застосовується модифікація ТТФ або шляхом введення замісників біля атомів карбону (рис. 2а), або ж утворенням так званого прозширеного рТТФ фрагменту, коли олефіновий зв'язок замінюється іншою структурою із кратними зв'язками із збереженням спряженої будови (рис. 2в).

В попередніх роботах було продемонстровано широкий спектр використання рТТФ у молекулярній електроніці [20], яка має можливість оборотньо змінювати геометрію при окисненні від вигнутої форми для нейтральної молекули до планарної форми дикатіона (рис. 3). Пізніше нашою групою було отримано самозбірні капсули з оборотним інкапсулюванням молекули-гостя та вивільненням за рахунок зміни геометрії ліганду і відповідно капсули при окисненні [21-23]. 

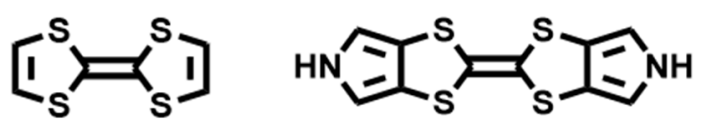

6

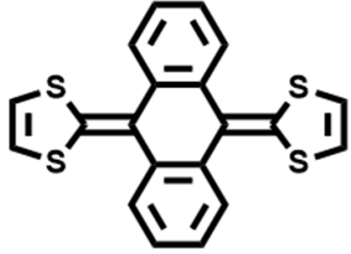

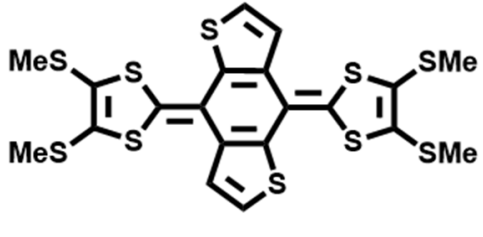

1

Рис. 2. ТТФ та його похідні: ТТФ (а); біс-піроло-ТТФ (б); п-розширена-ТТФ (рТТФ, ехТТF) (в); дітієно-ТТФ (г)

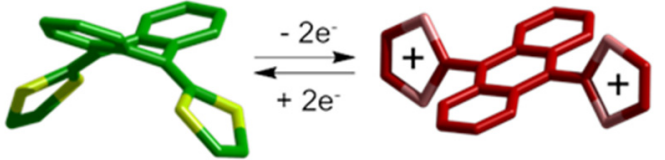

Рис. 3. Геометрія рТТФ(ехTTF) у нейтральному та окисненому стані

У даній роботі ми були зацікавлені в дослідженні подальшої модифікації рТТФ фрагменту шляхом зміни структури ароматичного фрагменту в центрі сполуки. Так, для серії біс-тіазолопохідних з бензо[1,2-d:4,5d']біс(тіазольним) ядром (BВT) [24] було розраховано та проілюстровано на модельних сполуках вплив нековалентних взаємодій S-S на стабілізацію геометрії молекули. Нам вдалось отримати рентгеноструктурні дані для нейтральної молекули, однак для підтвердження геометрії окисненої форми було застосовано метод електрокристалізації.

Основні вимоги використання даного методу полягають у використанні сполук, що при окисненні дають стабільний радикал, який далі переходить в розчин. Однак при правильному підборі таких умов, як концентрація, розчинник, температура, густина струму та протиіон, можна досягти утворення кристалів (рис. 4). Використання стабільного постійного струму дозволяє мати гнучкий контроль за кінетикою окиснення, що, в свою чергу, відповідає концентрації окисненої форми та регулює швидкість росту кристалів. Решта вищезгаданих параметрів впливає на розчинність окисненої форми. Саме від їх вдалого поєднання залежить успіх експерименту.

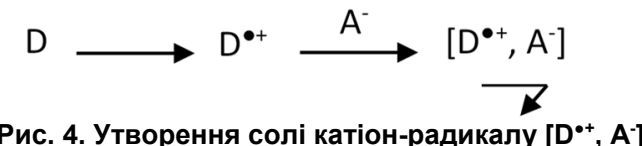

Для експерименту використовується стандартна U-подібна електролітична комірка (рис. 5). Пориста скляна перегородка розділяє два відділення та не дозволяє змішуватись продуктам, що утворюються на аноді та катоді, при цьому зберігаючи електричне коло. Це дозволяє уникнути забруднення цільових кристалів домішками інших продуктів відновлення, якщо такі є. Особливо важливою $є$ чистота комірки, тому перед кожним експериментом використовувалась баня із суміші $\mathrm{H}_{2} \mathrm{SO}_{4} / \mathrm{H}_{2} \mathrm{O}_{2}$ із наступною промивкою водою, метанолом, ацетоном та сушкою в печі.

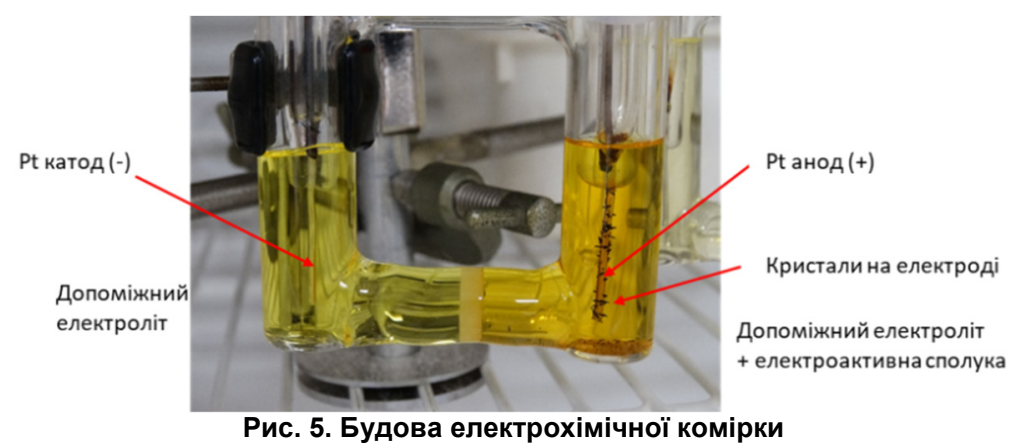

Як електроди використовується платиновий дріт діаметром 1 мм та довжиною 2 см. Якість поверхні електроду також $\epsilon$ надзвичайно важливою, тому перед експериментом електроди спочатку механічно поліруються наждачним папером, після чого піддаються електролізу в $1 \mathrm{M} \mathrm{H}_{2} \mathrm{SO}_{4}$.

Вплив параметрів експерименту. У даному розділі наведено аналіз даних літератури щодо впливу основних параметрів експерименту на ефективність методики.

Розчинник. Одна з основних вимог до розчинника стабільність протягом експерименту. Наступною вимогою є висока розчинність вихідної сполуки та підтримуючого електроліту у поєднанні з низькою розчинністю солі окисненої форми. Використання суміші розчинників також $€$ припустимим. Дуже важливим параметром $є$ чистота, у більшості випадків достатньо використання розчинників високого рівня чистоти (HPLC) із наступною очисткою на основному оксиді алюмінію. Загальний об'єм розчинника становить 10-15 мл. Перед закриттям комірки до початку експерименту обидва відділення дегазуються пропусканням аргону.

Параметри струму. Є два основних методи проведення електрокристалізації: гальваностатичний (контроль інтенсивності) та потенціостатичний (контроль потенціалу). У даній роботі використовувався гальваностатичний режим. Це дає змогу контролювати кількість електронів, перенесених на катод, і тим самим контролювати кількість катіонів, утворених на аноді. У результаті ми маємо сталу швидкість росту кристалів, що дозволяє отримати кристали кращої якості. Інтенсивність струму, як правило, дорівнює порядку $\mu$ А. Можна визначити час, необхідний для повного окиснення сполуки, за наступними рівняннями:

$$
Q=i \cdot t=n \cdot N \cdot F, t=\frac{n N F}{i},
$$

де $Q$ - заряд (Кл), $i$ - силу струму (А), $t$ - час (с), $n$ - кількість електронів, що беруть участь в електрохімічному процесі, $N$ - кількість молів електроактивної сполуки, $F$ - константа Фарадея. 
Відповідно, чим нижче сила струму, тим повільніше ростуть кристали, що в свою чергу сприяє отриманню кристалів кращої якості. А потенціостатичний режим рідко використовується для отримання монокристалів внаслідок нестабільного темпу росту, що, у свою чергу, негативно впливає на якість кінцевих кристалів. На практиці використовується значення в 0,5-1 $\mu \mathrm{A}$.

Концентрація. Стандартним діапазоном роботи $€$ концентрації від $(0,1-1) \cdot 10^{-3} \mathrm{M}$, що дозволяє отримувати оптимальні результати без надлишкового використання вихідних речовин. Допоміжний електроліт використовується в надлишку (зазвичай $0,1 \mathrm{M}$ ), що забезпечує як достатню провідність розчину, так і достатню кількість протиіонів для утворення солі. При використанні більш дорогих електролітів допустимо знижувати концентрацію до 0,01 М, але це вважається менш бажаним.

Температура. Вважається одним із важливих чинників, що дозволяє контролювати швидкість кристалізації утвореної солі. Розчинність $€$ функцією температури: чим вона вища, тим краща розчинність солі. Відповідно, зниження температури приводить до повільнішого осадження, що сприяє утворенню більш якісних кристалів. Проте не варто занадто сильно охолоджувати розчин, оскільки можуть втратити розчинність вихідні сполуки. На практиці оптимальний діапазон лежить у межах 5- $45^{\circ} \mathrm{C}$. Для підтримки сталої температури використовуються бані або термостатичні шафи.

Допоміжний електроліт. Основне завдання допоміжного електроліту полягає в забезпеченні достатньої провідності, що досягається відповідною концентрацією. Іншим, гнучкішим параметром $\epsilon$ вплив аніона, який далі переходить в цільову сіль окисненої форми. На практиці використовується велике різноманіття допоміжних електролітів. Як катіони найчастіше використовують тетрабутил-, тетрагексиламоній або тетрафенілфосфін залежно від вибору розчинника. Вибір аніонів дуже широкий, їх зазвичай класифікують за геометрією: моноатомні $\left(\mathrm{Cl}^{-}\right.$ , $\mathrm{Br})$, плоскі $\left(\mathrm{NO}_{3}{ }^{-}\right)$, тетраедричні $\left(\mathrm{ClO}_{4}^{-}, \mathrm{ReO}_{4}^{-}\right)$, октаедричні $\left(\mathrm{PF}_{6}^{-}, \mathrm{SbF}_{6}^{-}, \mathrm{AsF}_{6}^{-}\right)$, лінійні $\left(\mathrm{I}_{3}^{-}, \mathrm{Aul}_{2}^{-}, \mathrm{Ag}(\mathrm{CN})_{2}^{-}\right)$, двовимірні (Cu(NCS) $\left.2^{-}\right)$. Основним обмеженням $€$ стабільність в умовах експерименту. Допоміжний електроліт очищують перекристалізацією.

Експериментальна частина. Розчинники високої чистоти (HPLC grade) тетрагідрофуран та дихлорометан додатково очищали шляхом пропускання через основний $\mathrm{Al}_{2} \mathrm{O}_{3}$, використовували комерційні допоміжні електроліти, які додатково перекристалізовували перед експериментом. 4,8-Біс(4,5-біс(метилтіо)-1,3-дитіол-2іліден)-4,8-дигідробензо[1,2-b:4,5-b']дитіофен отримували відповідно до літературних методів.

Експериментальні умови електрокристалізації

\begin{tabular}{|l|l|l|l|l|}
\hline Розчинник & \multicolumn{1}{|c|}{ Аніон } & Температура, ${ }^{\circ} \mathbf{C}$ & Сила струму, мкA & \multicolumn{1}{c|}{ Результат } \\
\hline $\mathrm{CH}_{2} \mathrm{Cl}_{2}$ & $n \mathrm{Bu}_{4} \mathrm{NPF}_{6}$ & 20 & 0,5 & Декілька кристалів, не вдалось отримати структуру \\
\hline $\mathrm{CH}_{2} \mathrm{Cl}_{2}$ & $n \mathrm{Bu}_{4} \mathrm{NPF}_{6}$ & 20 & 0,5 & Фіолетовий осад \\
\hline $\mathrm{CH}_{2} \mathrm{Cl}_{2}$ & $n \mathrm{Bu}_{4} \mathrm{NClO}_{4}$ & 20 & 0,5 & Фіолетовий осад \\
\hline $\mathrm{CH}_{2} \mathrm{Cl}_{2}$ & $n \mathrm{Bu}_{4} \mathrm{NPF}_{6}$ & 10 & 0,5 & Фіолетовий розчин і осад \\
\hline $\mathrm{T} Ф$ & $n \mathrm{Bu}_{4} \mathrm{NPF}_{6}$ & 10 & 0,5 & Темні голчаті кристали \\
\hline
\end{tabular}

У результаті було отримано сіль катіон-радикалу $\left(1^{-+}\right) \cdot \mathrm{PF}^{6-}$. При цьому варто зазначити, що продукт $€$ відмінним від більш поширених солей дикатіона для інших сполук на основі рТТФ. Це, імовірно, зумовлено відносно швидким випаданням в осад солі катіон-радикалу та відповідним утворенням кінетичного продукту [25]. Вдалий підбір умов дозволив спостерігати утворення кристалів вже на 3 день і через 7 днів розчин був прозорим із темними голчатими кристалами на електроді.

Висновки. На основі аналізу даних літератури розроблено та випробувано низку умов для електрокристалізації. Використання помірної концентрації розчиненої речовини (порядку $10^{-3} \mathrm{M}$ ) дозволило оптимізувати загальну кількість речовини, необхідної для серії експериментів. Сила струму підтримувалась на рівні $0,5 \mu \mathrm{A}$, що дозволило поєднати ефективну швидкість росту кристалів із загальним часом експерименту в межах 1-2 тижнів. Як допоміжний електроліт було використано більш поширені тетрабутиламонієві солі з аніонами $\mathrm{ClO}_{4}^{-}$та $\mathrm{PF}_{6}^{-}$. Через особливості вихідної речовини вибір розчинників було обмежено дихлорметаном та тетрагідрофураном, при цьому саме останній виявився найбільш ефективним. У результаті електрокристалізації було отримано бажані кристали солі катіон-радикалу $\left(1^{*}\right)^{*} \mathrm{PF}^{6-}$.

Список використаних джерел

1. Bard A.J., Faulkner L.R. Electrochemical Methods: Fundamentals and Applications. 2nd Ed. New York ; London : Wiley-Interscience, 2000, 856 p.

2. Bond A.M. Broadening Electrochemical Horizons: Principles and Illustration of Voltammetric and Related Techniques. Oxford : Oxford University Press., 2002, 513 p.

3. Compton R.G., Laborda E., Ward K.R. Understanding voltammetry: Simulation of electrode processes. London : Imperial College Press, 2014, 249 p.

4. Chiang T.C., Reddoch A.H., Williams D.F., J. Chem. Phys., 1971, 54(5), 2051-2055.
5. Coleman L.B., Cohen M.J., Sandman D.J., Yamagishi F.G., Garito A.F., Heeger A.J., Solid State Commun., 1973, 12(11), 1125-1132.

6. Ferraris J., Cowan D.O., Walatka V., Perlstein J.H., J. Am. Chem. Soc., 1973, 95(3), 948-949.

7. Wudl F., Smith G.M., Hufnagel E.J., J. Chem. Soc., Chem. Commun., $1970,21,1453-1454$.

8. Wudl F., Acc. Chem. Res., 1984, 17(6), 227-232.

9. Melby L.R., Harder R.J., Hertler W.R., Mahler W., Benson R.E., Mochel W.E., J. Am. Chem. Soc., 1962, 84(17), 3374-3387.

10. Schukat G., Fanghänel E., Sulfur Rep., 1993, 14(1), 245-383.

11. Kathirgamanathan P., Mucklejohn S.A., Rosseinsky D.R., J. Chem. Soc., Chem. Commun., 1979, 2, 86-87.

12. Bechgaard K., Carneiro K., Rasmussen F.B., Olsen M., Rindorf G., Jacobsen C.S., Pedersen H.J., Scott J.C., J. Am. Chem. Soc., 1981, 103(9), 2440-2442.

13. Mishra A., Bäuerle P., Angew. Chem. Int. Ed., 2012, 51(9), 2020-2067.

14. Zhilyaeva E.I., Torunova S.A., Shilov G.V., Flakina A.M., Yudanova E.I., Lyubovskaya R.N., Russ. Chem. Bull., 2017, 66(6), 986-990.

15. Ashoka Sahadevan S., Monni N., Abhervé A., Auban-Senzier P., Canadell E. Mercuri M.L., Avarvari N., Inorg. Chem., 2017, 56(20), 12564-12571.

16. de Caro D., Faulmann C., Valade L., Jacob K., Cormary B., Fr.-Ukr. J. Chem., 2016, 4(1), 65-75.

17. Murphy A.R., Fréchet J.M.J., Chem. Rev., 2007, 107(4), 1066-1096.

18. Lin Y., Li Y., Zhan X., Chem. Soc. Rev., 2012, 41(11), 4245-4272.

19. Zhao X., Wang M., Mater. Today Energy, 2018, 7, 208-220.

20. Brunetti F.G., Lopez J.L., Atienza C., Martin N., J. Mater. Chem., 2012, 22(10), 4188-4205.

21. Croué V., Goeb S., Szalóki G., Allain M., Sallé M., Angew. Chem. Int. Ed., 2016, 55(5), 1746-1750.

22. Szaloki G., Croue V., Allain M., Goeb S., Salle M., Chem. Commun., 2016, 52(65), 10012-10015.

23. Szalóki G., Croué V., Carré V., Aubriet F., Alévêque O., Levillain E., Allain M., Aragó J., Ortí E., Goeb S., Sallé M., Angew. Chem. Int. Ed., 2017, 56(51), 16272-16276.

24. Conboy G., Spencer H.J., Angioni E., Kanibolotsky A.L., Findlay N.J., Coles S.J., Wilson C., Pitak M.B., Risko C., Coropceanu V., Bredas J.-L., Skabara P.J., Mater. Horizons, 2016, 3(4), 333-339.

25. Yoshiro Y., Katsuhiko O., Shoji T., Kenichi I., Hiroo I., Adv. Mater., 1994, 6(4), 295-298.

Надійшла до редколегії 30.05.18 
С. Крикун, асп., krykun.serhii@gmail.com,

И. Левков, канд. хим. наук,

Т. Егорова, канд. хим. наук,

3. Войтенко, д-рхим. наук,

Киевский национальный университет имени Тараса Шевченко, Киев

\section{СИНТЕЗ ОКИСЛЕННОЙ ФОРМЫ ДИТИЕНО-ТТФ МЕТОДОМ ЭЛЕКТРОКРИСТАЛЛИЗАЦИИ}

Исследован эффективный метод получения кристаллов окисленной формы, проанализировано влияние на ход процесса растворителей, температуры и поддерживающего электролита. Показано, что соединение дитиено-ТTФ кристаллизируется в форме соли радикал-катиона, в отличии от ожидаемого дикатиона.

Ключевые слова: электрокристаллизация, тетратиофульвален, ТТФ.

S. Krykun, PhD Student, krykun.serhii@gmail.com,

I. Levkov, PhD

T. Yegorova, PhD,

Z. Voitenko, Dr. Sci.

Taras Shevchenko National University of Kyiv, Kyiv

\section{SYNTHESIS OF THE OXIDIZED FORM OF DITHIENO-TTF BY ELECTROCRYSTALLIZATION}

General principles of the electrocrystallization technique in application to organic molecules are shown, as some historical background. Based on this, we were able to rationalize main variables in the experiment which are needed in order to get crystals of the oxidized form, that are suitable for further applications such as for example single crystal $x$-ray diffraction analysis or conductivity measurements. The biggest impact comes from such factors as choice of solvent and supporting electrolyte, which influence directly the solubility of both the starting compound and its oxidized form. Purity of all components is also paramount. In order to avoid formation of by-products, experiment is usually performed in a sealed U-shaped electrochemical cell with a glass filter between the anodic and cathodic compartments and under inert atmosphere such as argon or nitrogen. Other parameters considered here, such as temperature of the solution and intensity of the current, help to fine-tune the result, but have less impact on whether the crystallization will occur at all. It is also critical to maintain both parameters at constant values in order to obtain high quality single crystals. Galvanostatic oxidation mode is more favourable comparing to the potentiostatic as it allows steady rate of oxidation by providing fixed intensity of the electrical current and subsequently more stable rate of crystal grows, although potentiostatic mode or alternating current can be used to grow bigger amounts when quality of the single crystal is less important. Further we used this approach to electrocrystalize previously obtained by our group dithieno-TTF, based on the exTTF scaffold. According to the literature cyclic voltammetry data, dithieno-TTF undergoes reversible single-wave two electron oxidation to form bis-cation similar to classic exTTF, but in our case only radical-cation salt was obtained in a form of shiny, dark-red, needle-like single crystals. This could be attributed to its extremely low solubility and corresponding formation of the kinetic product, which correlate well with relatively fast crystallization just within 3 days. Another possibility is a comproportionation reaction involving the starting neutral molecule and oxidized dication.

Keywords: electrocrystallization, tetrathiafulvalene, TTF.

УДК 541.64:615.272

DOI: https://doi.org/10.17721/1728-2209.2018.1(55).15

Л. Куницька, канд. хім. наук,

Т. Желтоножська, д-р хім. наук

Київський національний університет імені Тараса Шевченка, Київ

\section{ЗАКОНОМІРНОСТІ КИСЛОТНОГО ГІДРОЛІЗУ БЛОК-КОПОЛІМЕРІВ, ЩО МІСТЯТЬ ПОЛІАКРИЛАМІД ТА ПОЛІЕТИЛЕНОКСИД}

Досліджено особливості кислотного гідролізу міцел диблок-кополімерів ПЕО-b-ПАА (ДБК) і триблок-кополімерів ПАА-bПЕО-b-ПАА (ТБК) у водному середовищі. Методом потенціометричного титрування розглянуто кінетичні закономірності протікання реакції кислотного гідролізу ДБК та ТБК при різній довжині ПЕО- та ПАА-блоків порівняно з поліакриламідом (ПАА). Встановлено, що процес гідролізу диблок- та триблок-кополімерів залежить від довжини ПЕО- і ПАА-ланцюгів і $є$ більш ефективним для блок-кополімерів з більшою довжиною обох блоків.

Ключові слова: блок-кополімери, поліакриламід, поліетиленоксид, кислотний гідроліз.

Вступ. Міцели полімерів успішно замінили традиційні носії лікарських препаратів, такі як міцелярні та везикулярні структури ліпідів, неорганічні і полімерні наночастинки, нано- та мікрочастинки емульсій [1-4]. Більшість робіт в цій галузі виконувалась за межами України. Між тим, на кафедрі хімії мономерів і полімерів розроблено нові міцелярні наноконтейнери, які $є$ продуктами самозбирання асиметричних блок-кополімерів 3 хімічно комплементарними блоками, що містять поліакриламід (ПАА) та поліетиленоксид (ПЕО) [5-7]. Встановлена їх висока ефективність при інкапсуляції протиракового препарату доксорубіцину [8-10].

Здійснення адресної доставки лікарських препаратів за допомогою міцелярних наноконтейнерів передбачає наявність лігандів-сахаридів в верхніх шарах гідрофрільної "корони" міцел [11]. Тільки в такому випадку на поверхні клітин реалізується взаємодія лігандів з рецепторами, яка запустить механізм ендоцитозу і подальшого проникнення наноконтейнерів в середину клітин, де відбуватиметься їх біодеградація і вивільнення лікарської речовини [12]. Щоб мати ліганди-сахариди в верхніх шарах міцелярної "корони", необхідно вводити їх в гідрофільні блоки міцелоутворюючих блок-кополімерів безпосередньо в ході їх синтезу, або в процесі подальшої функціоналізації синтезованих кополімерів.

Сьогодні значна увага прикута до галактози як вектору на міцелярних носіях. Рецептори, що розпізнають галактозу (азіалоглікопротеїн), містять клітини печінки та легенів, які вважаються первинним місцем знаходження метастазів пухлин $[13,14]$. Найпоширенішим і доступним препаратом галактози, який випускається багатьма хімічними концернами світу, є галактозамін. Його можна легко в м'яких умовах "пришити" до тих чи інших полімерних ланцюгів, що містять активні гідроксильні, карбоксильні та амінні групи, за допомогою зшиваючого агенту карбонілдіімідазолу [15-17], який також є доступним на ринку. Таким чином, головною проблемою на шляху введення "векторів" галактози у верхні шари міцел стає створення однієї або декількох $-\mathrm{OH},-\mathrm{COOH}^{-}$або $-\mathrm{NH}_{2}$ груп в кінцевих частинах гідрофрільних блоків відповідних блок-кополімерів.

Для блок-кополімерів за участю ПАА існує можливість легкого перетворення активних амідних груп в карбоксильні або амінні шляхом реакцій гідролізу або амінометилювання акриламідних ланок [18]. Проте, використання для створення -COОН груп реакції лужного 